\title{
Research on the Production Mode of Chinese Film and Television Cartoons in the Post 2D Era
}

\author{
Yang Liu* \\ Science of Animation, School of Arts, Xuzhou University of Technology, Xuzhou 22100, China \\ *Corresponding Author email: tomcrazy@126.com
}

Keywords: post 2D era; film and television animated film; production mode

\begin{abstract}
In recent years, the scale of audiences in China's film and television animation has expanded significantly. Based on this, this paper mainly aims at the analysis of the common cartoon production mode in the post 2D era, from the aspects of culture and aesthetics, figure modeling and environmental design, cost and production time, elaborates the production mode of the film and TV cartoon in the post 2D era, in order to promote the improvement of the production quality of the film and television cartoons in China, and provide a good theoretical reference for the development of the film and TV animation industry in China.
\end{abstract}

\section{Introduction}

The gap between China's animation production and the United States, Japan and other countries is more obvious. Although the arrival of the post 2D era has brought new challenges to China's animation production industry, at the same time, it has also brought new opportunities for this industry. From the two main production modes or technologies of the post 2D era, the 2.5D production mode and the 3D full CG production model, the advantages of the two are different. How to establish the production mode that meets the requirements of the film and television animation production in China has become the main problem.

\section{The Main Animated Cartoon Production Mode in the Post 2D Era}

In the post 2D era, the animated cartoon model was based on 2.5D animated cartoon and 3D full computer graphics (CG). The comparison of these two production patterns is shown in Table 1. From table 1 , we can see that these two cartoons have different modes of production, and the animation effects produced by them are different.

Table 1 Comparison between 2.5D production mode and 3D computer graphics technology production mode

\begin{tabular}{ccc}
\hline Production mode & technical characteristics & Advantage \\
\hline 2.5D production mode & $\begin{array}{c}\text { Using 2D drawing method to } \\
\text { create character modeling, } \\
\text { and using computer and CG } \\
\text { modeling environment, props } \\
\text { and so on to synthesize. }\end{array}$ & $\begin{array}{c}\text { The introduction of 3D } \\
\text { technology highlights the } \\
\text { stereoscopic feeling of the } \\
\text { picture; the retention of 2D } \\
\text { technology keeps the } \\
\text { characters' hand drawn } \\
\text { charm. }\end{array}$ \\
$\begin{array}{c}\text { Made up of modeling, special } \\
\text { effect, rendering, material } \\
\text { and so on }\end{array}$ & $\begin{array}{c}\text { The animation process is } \\
\text { continuous and close, and } \\
\text { realizes the full integration of } \\
\text { art and technology. }\end{array}$ \\
\hline
\end{tabular}




\section{The Production Mode of Chinese Film and Television Cartoons in the Post 2D Era}

From the following aspects, this paper analyzes and studies the production mode of China's film and television animation in the post 2D era.

\subsection{Cultural and aesthetic aspects}

The Hollywood 3D animated cartoon of the United States mostly uses the CG mode of 3D production, the main reason is shown in Table 2. In recent years, no lack of 3D all CG film and television cartoon produced by the United States has been widely praised in China, such as the movie cartoons such as "robot mobilization", "taming Dragon Master", "crazy animal city" and so on, all of which have obtained the popular box office [2]. But from the style of film and television cartoons introduced by Disney and Hollywood in the United States, the plot of these cartoons, characters and so on are full of strong Western style. However, the audiences of Chinese film and television animation have some differences with American film and television animations in terms of cultural background and aesthetic preference. Therefore, in the post 2D era, the production of China's film and television animation needs to fully consider the actual needs of the audience. From this point of view, the 2.5D production model (mainly Japanese animated cartoon) has a certain buffer function in the style of film and television animation. Relatively speaking, this mode of production is more compatible with the cultural background and aesthetic preference of the Chinese audience, and its promotion has a good feasibility.

Table 2 reasons for the adoption of the 3D full CG model in the United States

\begin{tabular}{cc}
\hline Cause type & Effect \\
\hline Plentiful production cycle & $\begin{array}{c}\text { The production team can determine the best } \\
\text { production plan through a longer production } \\
\text { cycle. }\end{array}$ \\
$\begin{array}{c}\text { Technology lead } \\
\text { Hollywood has the world's leading 3D all CG } \\
\text { Technology }\end{array}$ \\
$\begin{array}{c}\text { 3D full CG technology fully meets the role of } \\
\text { movie animation production needs. }\end{array}$ \\
\hline
\end{tabular}

\subsection{Figure modeling and environmental design}

In the production process of film and television animation, character modeling, props and environmental design are undoubtedly the top priority. In order to ensure the quality of movie and TV animations, we need to design the characters, props and environment according to the content and requirements of animated cartoons.

As far as characters are concerned, 3D full CG technology can highlight the stereoscopic feeling of characters, while 2D technology can reflect the affinity of hand drawn. For example, the characters in the animated cartoon "Qi Jiguang" are all designed by 3D technology, and the characteristics of their main characters are shown in Table 3. Therefore, in the production process of film and television animation, we should fully combine the production needs of animated cartoons and make appropriate selection of production techniques.

Table 3 characteristics of the main characters in "Qi Jiguang"

\begin{tabular}{cc}
\hline Dominating figure & Application advantages of 3D Technology \\
\hline Qi Jiguang & $\begin{array}{c}\text { Using 3D technology to deal with Qi Jiguang's } \\
\text { military uniform, he can create a heroic image } \\
\text { capable of being able, capable and brave. } \\
\text { The integration of the heroes and the beauty } \\
\text { with 3D Technology }\end{array}$ \\
Qi Ji Mei & $\begin{array}{c}\text { Using 3D technology to highlight people's } \\
\text { ingenuity and intelligence }\end{array}$ \\
\hline
\end{tabular}


From an environmental point of view, the environment can play a role of rendering atmosphere and theme. In 2D animation techniques, environmental factors such as rain and snow and water flow can be realized by circular skills and layering techniques. But judging from the production effect, 3D technology is obviously more advantageous. The application scope of 3D technology in the production of animation environment elements is shown in Table 4.

Table 4 the application scope of 3D technology in the production of animation environment elements

\begin{tabular}{cc}
\hline Application object & Application advantage \\
\hline blast & 3D technology can restore real scenes and \\
create a tense atmosphere. \\
smoke & $\begin{array}{c}\text { 3D technology can make smog } \\
\text { environment more lifelike. }\end{array}$ \\
Waterfall & $\begin{array}{c}\text { Treating waterfalls with 3D technology } \\
\text { can create a quiet atmosphere }\end{array}$ \\
\hline
\end{tabular}

\subsection{Cost and production time}

Plot and character is undoubtedly an important index for audience to evaluate high-quality video and animation. Usually, realistic personas and complex and reasonable plots are more in line with the audience's needs. This requirement makes the production cost of video animation increase significantly. Similarly, the above requirements also put a certain test on the production time of film and television animation.

Therefore, in order to ensure audience ratings of film and television animation, the production team should take into account both the production efficiency and production quality of the animation, and fully integrate the needs of the audience. Elaborately producing characters, plots and props of animated cartoons will lay a good foundation for the development of China's film and television animation.

\section{Conclusion}

To sum up, the advent of the post 2D era has brought rich opportunities and challenges for the production and development of China's film and television animation. In the current background, the production team should make full use of the psychology and demand of the audience and make use of the suitable production mode to create high quality and high efficiency film and television cartoons, and then improve the competitiveness of the film and TV animation industry in China, and make up the blank of the high precision products of the current film and TV animation industry of our country.

\section{References}

[1] Ming Z, Liu Y, Ouyang S, et al. Nuclear energy in the Post-Fukushima Era: Research on the developments of the Chinese and worldwide nuclear power industries[J]. Renewable \& Sustainable Energy Reviews, 2016, 58:147-156.

[2] Jie Y U, Subramanian N, Ning K, et al. Product delivery service provider selection and customer satisfaction in the era of internet of things: A Chinese e-retailers' perspective[J]. International Journal of Production Economics, 2015, 159:104-116.

[3] Raimondi C, Nicolazzo C, Gradilone A. Circulating tumor cells isolation: the "post-EpCAM era”[J]. Chinese Journal of Cancer Research, 2015, 27(5):461-470.

[4] Li J, Pan W, Yin Y, et al. Prevalence and correlates of mitral regurgitation in the current era: an echocardiography study of a Chinese patient population[J]. Acta Cardiologica, 2016, 71(1):55-60.

[5] Liu Y, Li L, Shi S, et al. Association study of ankylosing spondylitis and polymorphisms in ERAP1 gene in Zhejiang Han Chinese population.[J]. Rheumatology International, 2016, 
36(2):243-248.

[6] Zhao E H, Ling T L, Cao H. Current status of surgical treatment of gastric cancer in the era of minimally invasive surgery in China: Opportunity and challenge[J]. International Journal of Surgery, 2016, 28:45-50.

[7] Camps A, Font J, Vall-Llossera M, et al. Determination of the sea surface emissivity at L-band and application to SMOS salinity retrieval algorithms: Review of the contributions of the UPC-ICM[J]. Radio Science, 2016, 43(3):1-16. 